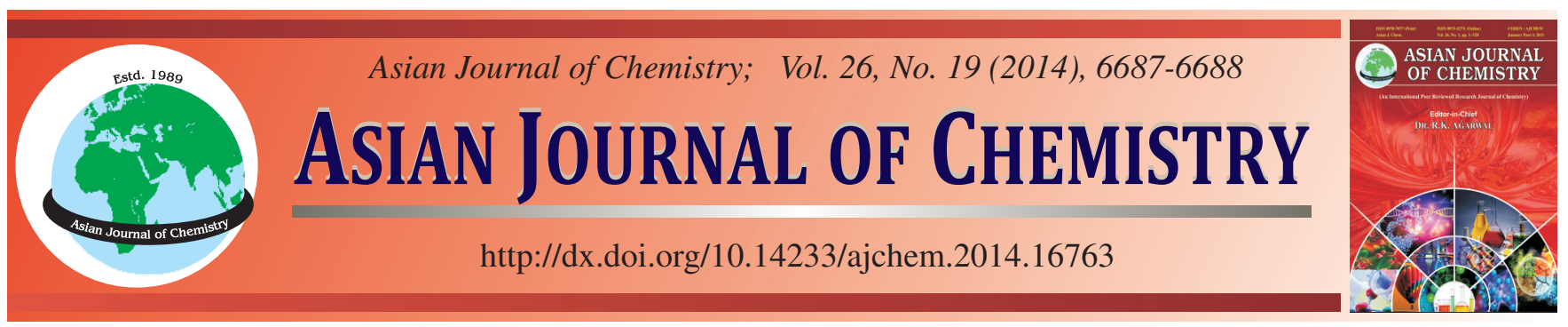

NOTE

\title{
Synthesis and Structural Characterization of Diiron Ethanedithiolate Complex $\left[\left(\mu-\mathrm{SCH}_{2}\right)_{2} \mathrm{Fe}_{2}(\mathrm{CO})_{4}\right]\left(\mathrm{PPh}_{3}\right)_{2}$ Related to the Active Site of $[\mathrm{Fe}-\mathrm{Fe}]-H y d r o g e n a s e s$
}

\author{
Wei Gao, Ting-Ting Zhang and Yan-Jun Sun*
}

School of Pharmacy, Henan University of Traditional Chinese Medicine, Zhengzhou 450046, P.R. China

*Corresponding author: E-mail: weigao415@aliyun.com

A diiron ethanedithiolate complex $\left[\left(\mu-\mathrm{SCH}_{2}\right)_{2} \mathrm{Fe}_{2}(\mathrm{CO})_{4}\right]\left(\mathrm{PPh}_{3}\right)_{2}(\mathbf{1})$, as the active site of $[\mathrm{Fe}-\mathrm{Fe}]$-hydrogenases, has been prepared and characterized. The title complex was prepared by reaction of $\left[\left(\mu-\mathrm{SCH}_{2}\right)_{2}\right] \mathrm{Fe}_{2}(\mathrm{CO})_{6}(\mathbf{A})$ with $\mathrm{PPh}_{3}$ at reflux in xylene in $50 \%$ yield. The new complex was characterized by IR, ${ }^{1} \mathrm{H}$ NMR, ${ }^{31} \mathrm{P}$ NMR and ${ }^{13} \mathrm{C}$ NMR spectroscopy.

Keywords: Diiron ethanedithiolate, Triphenylphosphine, Synthesis, Characterization.

In recent years, butterfly $[2 \mathrm{Fe}-2 \mathrm{~S}]$ have received special attention due to their unique structure and close relationship with the natural enzymes of $[\mathrm{Fe}-\mathrm{Fe}]$-hydrogenases ${ }^{1}$. Protein crystallographic studies revealed that the active site of [Fe-Fe]hydrogenases consists of a butterfly [2Fe-2S] cluster linked to a cubane-like [4Fe-4S] cluster via the sulfur atom of a cysteinyl group $^{2}$. Based on structural information, a good number of diiron dithiolate complexes ${ }^{3-5}$ were prepared and structurally characterized by various techniques ${ }^{6}$ in order to mimic the natural properties of [Fe-Fe]-hydrogenases. In this paper, we report the synthesis and structural characterization of diiron ethanedithiolate complex related to the active site of [Fe-Fe]hydrogenases.

Reaction and operation was carried out under a dry, oxygen free nitrogen atmosphere with standard Schlenk and vacuum line techniques. Acetonitrile was distilled with $\mathrm{CaH}_{2}$ under $\mathrm{N}_{2} \cdot \mathrm{Me}_{3} \mathrm{NO} \cdot 2 \mathrm{H}_{2} \mathrm{O}, \mathrm{PPh}_{3}$ and other materials were commercially available and used as received. Complex A was prepared according to the literature procedures ${ }^{7}$. IR spectra were recorded on a Nicolet 670 FTIR spectrometer. ${ }^{1} \mathrm{H}\left({ }^{31} \mathrm{P},{ }^{13} \mathrm{C}\right) \mathrm{NMR}$ spectra were obtained on a Bruker Avance $500 \mathrm{MHz}$ spectrometer.

Synthesis: A mixture of $\left(\mu-\mathrm{SCH}_{2}\right)_{2} \mathrm{Fe}_{2}(\mathrm{CO})_{6}(0.186 \mathrm{~g}, 0.5$ $\mathrm{mmol}), \mathrm{PPh}_{3}(0.262 \mathrm{~g}, 1 \mathrm{mmol})$ and xylene $(20 \mathrm{~mL})$ was refluxed for $4 \mathrm{~h}$ to give a brown-red solution. The solvent was reduced in vacuo and the residue was subjected to TLC separation using $\mathrm{CH}_{2} \mathrm{Cl}_{2}$ /petroleum ether ( $\left./ \mathrm{v}=1: 1\right)$ as eluent. Collecting the main red band afforded $0.201 \mathrm{~g} \mathrm{(48 \% )} \mathrm{of} 1$ as a red solid. Anal. Calcd. for $\mathrm{C}_{42} \mathrm{H}_{34} \mathrm{O}_{4} \mathrm{P}_{2} \mathrm{~S}_{2} \mathrm{Fe}_{2}$ : C, 60.02; $\mathrm{H}$, 4.08. Found: $\mathrm{C}, 60.31 ; \mathrm{H}, 4.24$. IR $\left(\mathrm{KBr}, \mathrm{v}_{\max }, \mathrm{cm}^{-1}\right)$ : $\mathrm{C} \equiv \mathrm{O}$ 1994 (vs), 1932 (vs). ${ }^{1} \mathrm{H}$ NMR (500 MHz, $\mathrm{CDCl}_{3}$ ): 7.58, 7.39 (2s, $30 \mathrm{H}, \mathrm{Ar}-\mathrm{H}), 1.57,1.28\left(2 \mathrm{~s}, 4 \mathrm{H}, 2 \mathrm{SCH}_{2}\right) \mathrm{ppm} .{ }^{31} \mathrm{P} \mathrm{NMR}$ (200 MHz, $\mathrm{CDCl}_{3}, 85 \% \mathrm{H}_{3} \mathrm{PO}_{4}$ ): 60.03 (s) ppm. ${ }^{13} \mathrm{C} \mathrm{NMR}$ (125 MHz, $\left.\mathrm{CDCl}_{3}\right):$ 216.78, $216.74(\mathrm{C} \equiv \mathrm{O}), 136.93,136.64$, $133.21,133.16,133.12,129.59,128.34,128.31$ (Ar-C), 32.83 $\left(\mathrm{CH}_{2}\right)$ ppm.

As shown in Scheme-I, treatment of complex A with 2 equivalent of $\mathrm{PPh}_{3}$ at reflux in xylene afforded the title complex $\mathbf{1}$ in $50 \%$ yield. The title complex $\mathbf{1}$ was air-stable red solids, which has been characterized by IR, ${ }^{1} \mathrm{H}$ NMR, ${ }^{31} \mathrm{P}$ NMR and ${ }^{13} \mathrm{C}$ NMR spectroscopy.

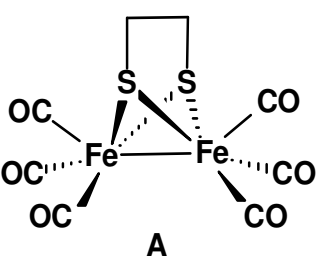

Scheme-1: Synthesis of the title complex $\mathbf{1}$

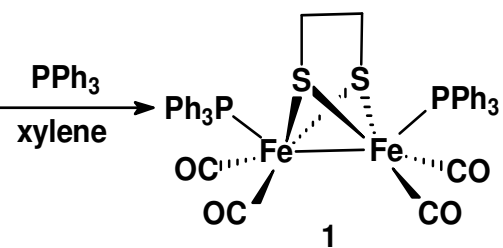

1
Infrared spectrum: As shown in Fig. 1, the IR spectrum of 1 displayed two strong absorption bands at 1993 and 1933 $\mathrm{cm}^{-1}$ for the terminal carbonyls and the $\mathrm{v}(\mathrm{C} \equiv \mathrm{O})$ values of complex 1 are shifted toward lower frequencies relative to the parent complex A $\left(2079,2039,2009,1996 \mathrm{~cm}^{-1}\right)^{7}$ because $\mathrm{PPh}_{3}$ is stronger electron donating than $\mathrm{CO}$.

${ }^{1}$ H NMR spectrum: As shown in Fig. 2, the ${ }^{1} \mathrm{H}$ NMR spectrum of 1 showed two singlets at $\delta 7.58$ and $7.39 \mathrm{ppm}$ for its phenyl protons and two singlets at $\delta 1.57$ and $1.28 \mathrm{ppm}$ for the methylene protons. 


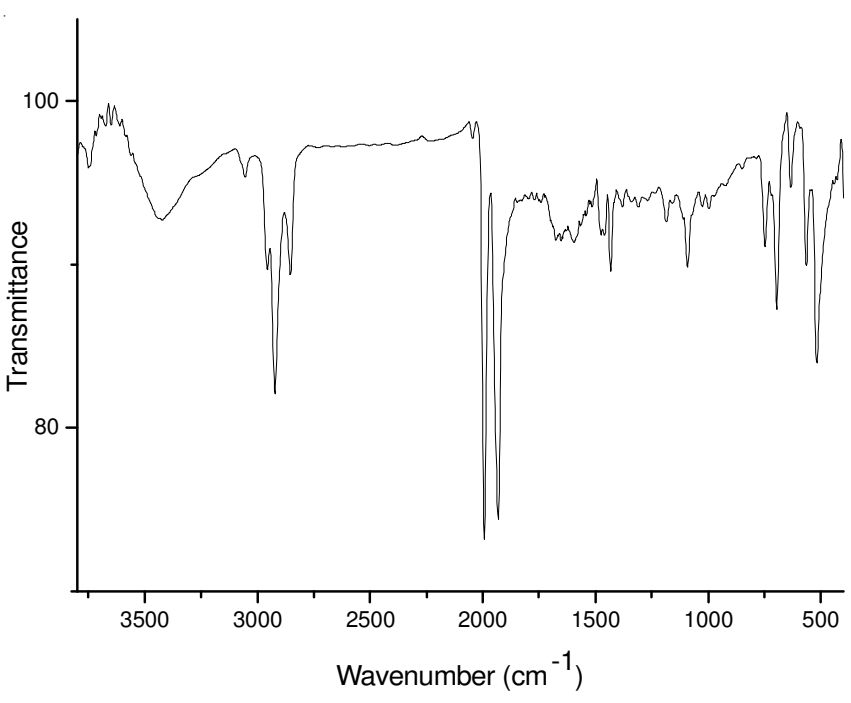

Fig. 1. IR spectrum of the title complex $\mathbf{1}$

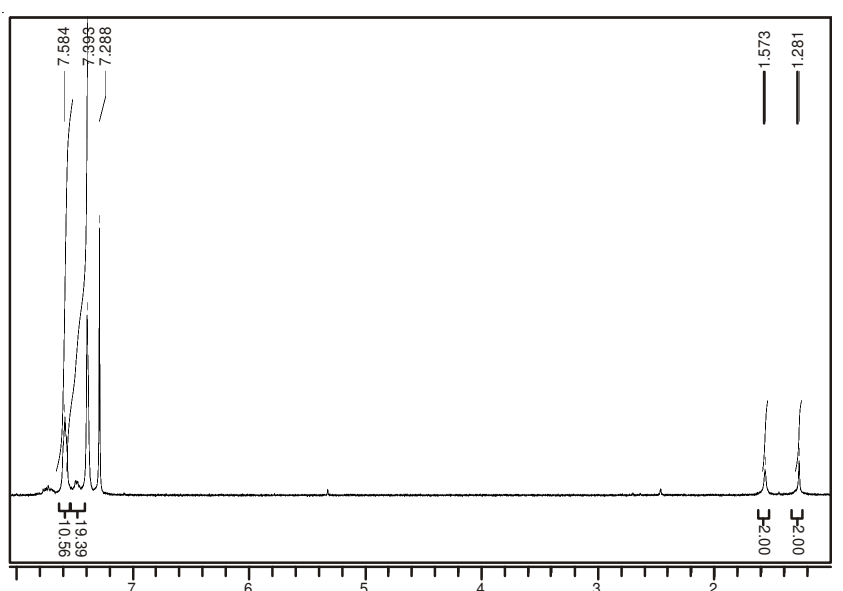

Fig. $2 .{ }^{1} \mathrm{H}$ NMR spectrum of the title complex 1

${ }^{31}$ P NMR spectrum: As shown in Fig. 3, the ${ }^{31}$ P NMR spectrum of 1 exhibited a singlet at $\delta 60.03$ ppm for the phosphorus atom of $\mathrm{PPh}_{3}$ coordinated to one Fe of the diiron subsite.

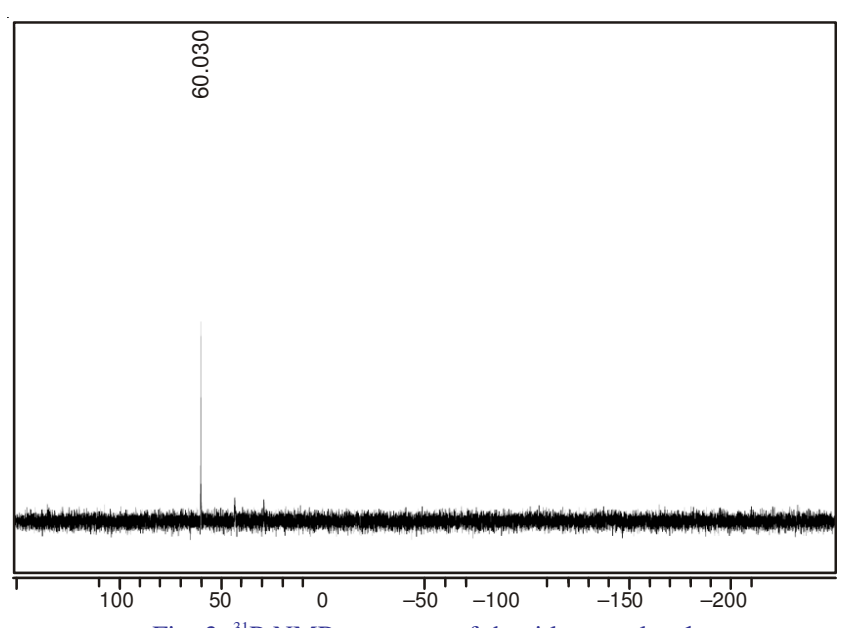

Fig. $3 .{ }^{31} \mathrm{P}$ NMR spectrum of the title complex 1
${ }^{13} \mathrm{C}$ NMR spectrum. As shown in Fig. 4 , the ${ }^{13} \mathrm{C}$ NMR spectrum of 1 demonstrated a doublet at $\delta 216.76 \mathrm{ppm}$ for the terminal carbonyls and a singlet at $\delta 32.83 \mathrm{ppm}$ for the methylene carbons.

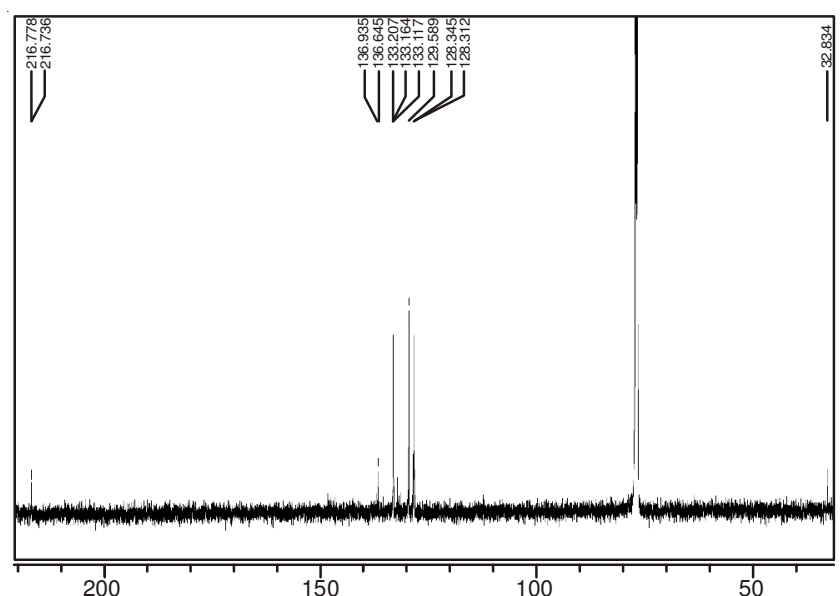

Fig. $4 .{ }^{13} \mathrm{C}$ NMR spectrum of the title complex $\mathbf{1}$

\section{ACKNOWLEDGEMENTS}

The authors gratefully acknowledge the financial support by the National Natural Science Foundation of China (31300284).

\section{REFERENCES}

1. (a) P.-H. Zhao, Y.-Q. Liu and G.-Z. Zhao, Polyhedron, 53, 144 (2013); (b) C.A. Mebi, D.S. Karr and B.C. Noll, Polyhedron, 50, 164 (2013); (c) P.H. Zhao, Y.Q. Liu and X.A. Li, Asian J. Chem., 25, 5428 (2013); (d) B.S. Yin, T.B. Li and M.S. Yang, J. Coord. Chem., 64, 2066 (2011); (e) X.F. Liu, Inorg. Chim. Acta, 378, 338 (2011); (f) X.F. Liu, X.W. Xiao and L.J. Shen, Transition Met. Chem., 36, 465 (2011).

2. (a) J.W. Peters, W.N. Lanzilotta, B.J. Lemon and L.C. Seefeldt, Science, 282, 1853 (1998); (b) Y. Nicolet, C. Piras, P. Legrand, C.E. Hatchikian and J.C. Fontecilla-Camps, Structure, 7, 13 (1999).

3. (a) X.F. Liu and B.S. Yin, J. Coord. Chem., 63, 4061 (2010); (b) X.F. Liu, Z.Q. Jiang and Z.J. Jia, Polyhedron, 33, 166 (2012); (c) X.F. Liu and H.Q. Gao, J. Clust. Sci., 25, 367 (2014); (d) X.F. Liu and H.Q. Gao, J. Clust. Sci., 25, 495 (2014).

4. (a) X.F. Liu, X.W. Xiao and L.J. Shen, J. Coord. Chem., 64, 1023 (2011); (b) X.F. Liu, J. Organomet. Chem., 750, 117 (2014).

5. (a) X.F. Liu and B.S. Yin, Z. Anorg. Allg. Chem., 637, 377 (2011); (b) X.F. Liu and X.W. Xiao, J. Organomet. Chem., 696, 2767 (2011); (c) W.M. Gao and J.M. Li, Acta Crystallogr. Sect. E Struct. Rep. Online, 68, m118 (2012).

6. (a) X.H. Liu, J.Q. Weng, C.X. Tan, L. Pan, B.L. Wang and Z.M. Li, Asian J. Chem., 23, 4031 (2011); (b) P.Q. Chen, C.X. Tan, J.Q. Weng and X.H. Liu, Asian J. Chem., 24, 2808 (2012); (c) Y.L. Xue, Y.G. Zhang and X.H. Liu, Asian J. Chem., 24, 5087 (2012); (d) L.J. Luo, X.F. Liu and H.Q. Gao, J. Coord. Chem., 66, 1077 (2013); (e) X.F. Liu and H.Q. Gao, Polyhedron, 65, 1 (2013).

7. A. Winter, L. Zsolnai and G. Huttner, Z. Naturforsch. C, 37b, 1430 (1982). 